\title{
Študij rudarstva in geotehnologije na Univerzi v Ljubljani od leta 1919 do danes
}

\author{
Željko Vukelić \\ Univerza v Ljubljani, Naravoslovnotehniška fakulteta, Oddelek za geotehnologijo, rudarstvo in okolje, Aškerčeva 12, \\ Ljubljana, Slovenija \\ *zeljko.vukelic@ntf.uni-lj.si
}

Zgodovinski podatki o razvoju slovenske univerze prikazujejo veliko željo za ustanovitev visoke šole na slovenskih tleh. Iz podatkov je razvidno, da so že davno premišljevali o uvedbi študija tehničnih predmetov, kot sta mehanika in jamomerstvo. Ta zahteva se pojavi s strani Kranjskih deželnih stanov v letih 1786-1787, ki so se sklicevali na rudnike živega srebra v Idriji, rudnike železove rude in na tovarne v Sloveniji, da bi tehnično osebje $\mathrm{v}$ rudnikih in tovarnah opravljalo svoje delo zadovoljivo. Zahtevo so podprli z ustanovitvijo prve rudarske akademije na svetu leta 1765 v Freibergu na Saškem. S prihodom Francozov v Ljubljano, ki so na tleh province Ilirije leta 1810 ustanovili Centralno šolo, je bilo omogočeno študirati inženirsko stroko. Študij naj bi trajal 4 leta, vendar ni nihče študija dokončal, ker je nova uredba ukinila študij za inženirje. Kljub večkratnim ponovnim poskusom, da bi Slovenija dobila univerzo, so se Slovencem te želje izpolnile šele po prvi svetovni vojni $\mathrm{z}$ razpadom Avstro-Ogrske monarhije.

V 19. stoletju je bilo rudarstvo v Sloveniji že precej razvito. Ob kovinskih rudnikih (Idrija, Mežica in drugi manjši), je imela Slovenija že pomembne premogovnike Senovo, Zagorje, Trbovlje, Hrastnik in Laško. Konec 19. stoletja pa se je pričela tudi proizvodnja lignita $\mathrm{v}$ Velenju. Strokovno osebje za te rudnike se je šolalo predvsem na avstrijski rudarski akademiji v Leobnu, vendar je bilo na domačih tleh slovenskih inženirjev sorazmerno malo.

Z ustanovitvijo Univerze v Ljubljani leta 1919, je zaživela tudi Tehniška fakulteta, ki je imela
5 oddelkov. Eden od teh je bil Rudarski oddelek. Slovenske narodnosti je bil samo en profesor in sicer dr. Karel Hinterlechner, ki je bil hkrati eden od ustanoviteljev ljubljanske univerze in prvi dekan Tehniške fakultete. Ostali učitelji so bili pretežno profesorji ruske narodnosti, ki so emigrirali iz Sovjetske zveze in so pred tem poučevali na rudarskih visokih šolah v Rusiji. Za ustanovitev Rudarskega oddelka v Ljubljani ima pomembne zasluge rudarski glavar Vinko Strgar. Na Tehniško fakulteto se je vpisalo 50 slušateljev, od tega 6 slušateljev za študij rudarstva. Vse do leta 1939 je bil Rudarski oddelek edini v tedanji Jugoslaviji in tudi na Balkanu. Leta 1939 so ustanovili Rudarski oddelek v Zagrebu, po drugi svetovni vojni pa še rudarske oddelke oziroma fakultete $v$ Beogradu, Tuzli in Boru.

Tik pred drugo svetovno vojno je pričel Rudarski oddelek zidati stavbo. Uspeli so dokončati železobetonsko skeletno konstrukcijo do strehe. Gradnja je bila med vojno prekinjena. Stavba v kateri danes domuje Oddelek za geotehnologijo, rudarstvo in okolje na Aškerčevi 12 v Ljubljani je bila dokončana leta 1950.

Znano je, da je bil študij rudarstva od nekdaj heterogen. Razen povsem rudarskih predmetov kot so bili: tehnično rudarstvo, bogatenje mineralnih surovin, globinsko vrtanje, rudarsko merjenje in geofizika, transport in izvažanje $\mathrm{v}$ rudnikih, je zajemal študij še geološke predmete, naravoslovne predmete in predmete s področja strojništva in elektrotehnike. Spričo take pestrosti študijske snovi, marsikateri slušatelj ni uspel končati študija prej kot v pe- 
tih letih, za večino pa je veljalo, da so porabili več časa.

Do leta 1931 je imel tedanji Rudarski oddelek dve rudarski organizacijski enoti - inštituta:

- Inštitut za rudarstvo,

- Inštitut za rudarska merjenje in geofizikalna raziskovanja.

V naslednjih letih se je Inštitut za rudarstvo reorganiziral v tri enote in tako so nastali štirje inštituti znotraj oddelka za rudarstvo in sicer:

- Inštitut za tehnično rudarstvo,

- Inštitut za separiranje in briketiranje rud in premoga ter za rudarsko gospodarstvo,

- Inštitut za rudarsko strojništvo,

- Inštitut za rudarska merjenje in geofizikalna raziskovanja.

Imena in naslovi teh enot so se večkrat menjavali in tako zasledimo tudi naslove: stolica, zavod in katedra. Po drugi svetovni vojni so zavodi dobili ime katedra, ki se je ohranilo do danes. Vse do šolskega leta 1949/50 je bil Rudarski oddelek v sestavu Tehniške fakultete Univerze v Ljubljani. Ko je bila leta 1950 ustanovljena Tehniška visoka šola, je Rudarski oddelek postal oddelek na Fakulteti za rudarstvo in metalurgijo. Tehniška visoka šola je združevala 6 fakultet. $\mathrm{V}$ tem obdobju se je prešlo na 10 semestrski študij. Sledilo je kar nekaj reorganizacij visokošolskega študija. V šolskem letu 1957/58 je Oddelek za rudarstvo prešel $v$ sestavo Fakultete za rudarstvo, metalurgijo in kemijsko tehnologijo (FRMKT), s šolskim letom 1959/60 pa je oddelek prevzel ime Oddelka za montanistiko. Šolsko leto 1960/61 je prineslo bistvene novosti v študij rudarske stroke. Predvidene so bile tri stopnje študija, katerih vsaka posebej je trajala 4 semestre. Študenti prve stopnje so dobili naziv inženir rudarstva, druge stopnje diplomirani inženir rudarstva in tretje stopnje magister rudarske stroke. Obenem je prišlo do reorganizacije fakultete in nastala je Fakulteta za naravoslovje in tehnologijo (FNT). Vse do šolskega leta 1965/66 se študijski program ni spreminjal. S tem letom se je znova prešlo na štiri semestrski študij I. in II. stopnje in na tri usmeritve v II. stopnji: eksploatacija, bogatenje in merstvo z geofiziko. Z letom $1968 / 69$ je bila prva stopnja študija ukinjena in prešlo se je na osem semestrski študij z navedenimi tremi os- novnimi usmeritvami. Zanimivo je, da je Oddelek za rudarstvo deloval znotraj Fakultete za naravoslovje in tehnologijo (FNT) vse do leta 1995, ko je bila ustanovljena Naravoslovnotehniška fakulteta (NTF), ki je združevala:

- Oddelek za geotehnologijo in rudarstvo,

- Oddelek za geologijo,

- Oddelek za materiale in metalurgijo,

- Oddelek za tekstilstvo,

- Oddelek za kemijsko izobraževanje in informatiko.

V obdobju med leti 1966 in 1995 ni prišlo do bistvenih sprememb v študijskem programu. Oddelek je imel v sestavi 4 katedre in sicer:

- Katedra za tehnično rudarstvo,

- Katedra za bogatenje mineralnih surovin,

- Katedra za rudarsko strojništvo, transport in elektrotehniko,

- Katedra za rudarsko merjenje in geofizikalno raziskovanje.

Študenti višjih letnikov so imeli možnost izbrati tri že omenjene osnovne usmeritve: eksploatacijo, bogatenje in merstvo z geofiziko. Zaradi vse večjega zanimanja stroke in gospodarstva na področjih podzemnih gradenj, ravnanjem $\mathrm{z}$ industrijskimi in komunalnimi odpadki, recikliranjem in izrabo alternativnih virov energije so na Oddelku za rudarstvo pričeli izvajati nov študijski program GEOTEHNOLOGIJA v šolskem letu 1993/94. Oddelek se je preimenoval v Oddelek za geotehnologijo in rudarstvo ter smiselno in vsebinsko preoblikoval štiri katedre:

- Katedra za tehnično rudarstvo in geotehniko, - Katedra za mehansko procesno tehniko in bogatenje mineralnih in sekundarnih surovin,

- Katedra za rudarsko strojništvo, transport, elektrotehniko in računalništvo,

- Katedra za rudarsko merjenje in geofizikalno raziskovanje.

Univerzitetni študij geotehnologije in rudarstva je trajal 8. semestrov in se zaključi z izdelavo diplomske naloge v 9. semestru. Diplomanti so po uspešno končanem študijo pridobili naziv univerzitetni diplomirani inženir geotehnologije in rudarstva. V šolskem letu 1997/98 se je pričel izvajati Visokošolski strokovni pro- 
gram geotehnologije in rudarstva, ki je bistveno bolj usmerjen $\mathrm{v}$ pridobivanje aplikativnih znanj s področja stroke. Diplomanti po uspešno končanem študijo pridobijo naziv diplomirani inženir geotehnologije in rudarstva.

Z vstopom Slovenije v Evropsko skupnost, je Slovenija morala izvesti reforme na področju visokega šolstva. Univerza v Ljubljani je pričela reformo visokega šolstva na podlagi Bolonjske deklaracije iz septembra 2003. Na Oddelku za geotehnologijo in rudarstvo je bil v letu 2005 prenovljen študijski program v skladu $\mathrm{z}$ bolonjskimi smernicami in Merili za akreditacijo študijskih programov. Program je pripravljen po sistemu $3+2+3$ :

\begin{tabular}{cc}
\hline $\begin{array}{c}\text { I stopnja (univerzitetni } \\
\text { dodiplomski študij) }\end{array}$ & trajanje: 3 leta \\
\hline $\begin{array}{c}\text { 2 stopnja (univerzitetni } \\
\text { podiplomski študij, magisterij) }\end{array}$ & trajanje: 2 leti \\
\hline 3 stopnja (doktorski študij) & trajanje: 4 leta
\end{tabular}

Program smo pripravili po Merilih za akreditacijo visokošolskih zavodov in študijskih programov, ki jih je sprejel Svet za visoko šolstvo Republike Slovenije (Uradni list RS, št. 63/04, 10.09.2004). Študijski program Geotehnologija in rudarstvo daje naravoslovno in tehniško izobrazbo, ki sledi razvoju $\mathrm{v}$ okviru strok geoznanosti. Vedno bolj pa se v tem okviru izkazuje potreba tudi po drugih znanjih, na primer iz ekonomike in informacijsko komunikacijske tehnologije (IKT).

Program daje študentom potrebna teoretična in praktična znanja za reševanje konkretnih strokovnih problemov v praksi, hkrati pa jih uvaja tudi v osnove raziskovanja, ki so potrebne za nadaljevanje študija na naslednjih stopnjah. $S$ programom študenti pridobijo kompetence za neposredno zaposlitev na najširšem področju pridobivanja mineralnih surovin, primarne predelave, podzemnih gradenj, vrtalne tehnike, dela za izvajanje merjenj in sledenj v naravi, dela za vrednotenje in izvajanje posegov v naravi, sanacije degradiranih površin, ravnanje z okoljem, trdnimi odpadnimi snovmi, itn. Pridobljena znanja in sposobnosti omogočajo uspešno delo na zahtevnejših strokovnih in tudi vodstvenih delovnih mestih tako $\mathrm{v}$ javnih kot tudi v zasebnih podjetjih.

Vsebina programa je prilagojena vsebinsko primerljivim študijskim programom s področja geotehnologije, geotehnike in rudarstva. Podobne študijske programe izvajajo na Montanistični univerzi v Leobnu - Avstrija, na Politehniki v Torinu - Italija, na Rudarski akademiji v Freibergu in Tehniški visoki šoli v Clausthalu - Nemčija. Poudarek je na študiju raznovrstnih aktivnosti, ki se odvijajo v zemeljski skorji z vključevanjem tehničnih in naravoslovnih znanstvenih polj. Težišča študijskega programa omogočajo mednarodno sodelovanje na interdisciplinarnih področjih, ki pokrivajo tehnično obravnavo gradnje podzemnih objektov, geotehnične gradnje, gospodarjenje z odpadki z vsemi pripadajočimi sklopi s področja okoljevarstvenega inženirstva, upravljanja podjetij in gospodarskih družb v zaokroženi celoti.

Leta 2015 se je oddelek zaradi vsebin poučevanja preimenoval v Oddelek za geotehnologijo, rudarstvo in okolje.

Danes je Oddelek za geotehnologijo, rudarstvo in okolje organiziran znotraj dveh kateder:

- Katedra za tehnično rudarstvo, geotehniko, geotermijo in urbano rudarjenje,

- Katedra za rudarsko merjenje in geofizikalno raziskovanje.

Do 31. decembra 2018 je na Oddelku za geotehnologijo, rudarstvo in okolje uspešno zaključilo študij naslednje število diplomantov:

\begin{tabular}{cc} 
STOPNJA ŠTUDIJA & $\begin{array}{c}\text { ŠTEVILO } \\
\text { DIPLOMANTOV }\end{array}$ \\
\hline Univerzitetni študij & 785 \\
\hline Študij I. stopnje & 31 \\
\hline Visokošolski strokovni študij & 77 \\
\hline Podiplomski študij, magisterij & 62 \\
\hline $\begin{array}{c}\text { Geotehnologija in rudarstvo } \\
\text { VS - 1. stopnja }\end{array}$ & 17 \\
\hline $\begin{array}{c}\text { Geotehnologija in okolje } \\
\text { UN - 1. stopnja }\end{array}$ & 40 \\
\hline Geotehnologija - 2. stopnja & 25 \\
\hline Doktorski študij & 29
\end{tabular}


